\title{
A bűnszervezetek és a költségvetési csalás kapcsolata Magyarországon
}

\section{BALLÁNÉ SZENTPÁLI Edit ${ }^{1}$}

\begin{abstract}
Magyarországon a rendszerváltást követő években korábban soha nem tapasztalt bűnözési hullám söpört végig. A bünözés új dimenziója nyílt meg azzal, hogy az elkövető egy egész szervezet súlyát, erejét tudta maga mögött. Kezdetben a szervezett bünözés egy része jellegzetesen a magas adótartalmú (jövedéki) termékekre, továbbá a jogosulatlan adó-visszaigénylésekre és más gazdasági jogsértésekre koncentrált. Az elkövetők a legális tevékenységgel elérhetőnél, lényegesen magasabb profitot tudtak megszerezni. 2015-től érzékelhetően növekedtek a bíróságokon az úgynevezett körbeszámlázásos ügyek. Ezekben az ügyekben számlabefogadó és kibocsátó gazdasági társaságok láncolatai szerepelnek, amelyek jelentős károkat okoztak az állami költségvetésnek. Ezek az esetek gyakran éveken keresztül felderítetlenek maradtak, míg végül a nyomozó hatóságok fel nem fedték azokat. Mind a vád, mind pedig a bíróság jogerös döntése szerint ezeket a cselekményeket bünszervezet keretében valósították meg. Az igazságügyi eljárások tapasztalatai alapján a búnszervezeteket mielöbb szét kell bontani. lgy a legkritikusabb kérdés az, miként csökkenthető az ehhez szükséges idő?
\end{abstract}

Kulcsszavak: költségvetési csalás, bűnszervezet, közgazdaság

\section{Bevezetés}

A politikai-gazdasági struktúraváltás, a gazdaság átalakításának ellentmondásai, a privatizáció, a társadalmi polarizáció és a bekövetkezett morális értékválság megteremtette a bűnözés minőségi változásának feltételeit, amelynek köszönhetően a rendszerváltást követő években korábban soha nem tapasztalt bűnözési hullám söpört végig Magyarországon. Korábban csak csírájában élő szervezett bűnözés mind erősebbé vált, struktúrája átalakult, kriminogén jegyei letisztultak, ismérvei törvényszerúvé váltak. ${ }^{2}$ A szervezett bűnözés új dimenziót nyitott a rendszerváltást követően Magyarországon azzal, hogy a tényleges elkövető egy egész szervezet súlyát, erejét tudta maga mögött és ez a súly, erő még inkább bátorította az elkövetőeket a szervezettel való együttműködés esetén, de fenyegető és gátló is volt abban az esetben, ha a szervezettel szembefordult. ${ }^{3}$

\footnotetext{
Dr. BALLÁNÉ Dr. SZENTPÁLI Edit, büntető bíró, Debreceni Törvényszék Edit SZENTPÁLI BALLÁNÉ, trial judge, Tribunal of Debrecen https://orcid.org/0000-0002-2173-9475, d.ballalajos@gmail.com

2 Bencze (2001) 46-47.

3 Bócz (2001) 5.
} 
A bíróságokon nagy számban fordul elő vagyon elleni, továbbá gazdasági bűncselekmény. E tényállásokkal összefüggésben az elmúlt néhány évben megszaporodott a bûnszervezetben elkövetett bűncselekmények száma. Ennek tükrében dolgozatom célja a 2012-2018 közötti időszakban elkövetett, és (bírói szakban) jogerősen befejezett költségvetési csalási ügyek vizsgálata. Ezeken az esetpéldákon keresztül mutatom be a bűnszervezeti keretek között történt elkövetés jogalkalmazói megítélésével kapcsolatos dilemmáinkat. A dolgozat a büntetéskiszabási gyakorlat elemzését nem tartalmazza, tekintettel arra, célom kizárólag a bűnszervezet fogalmának vizsgálatára terjed ki.

\section{A szervezett bưnözés történeti elözményei a rendszerváltásig}

A mai értelemben vett bűnbandák kriminális veszélyessége már évszázadokkal korábban, a felvilágosodás büntetőjogi gondolkodásában megjelent. Az 1795-ös Büntető Kódex-tervezetünk alapelvei között tartalmazta: ${ }^{4}$ „Ha többen társultak bűntettek elkövetésére, az ilyenben részt vevő vádlott - még abban az esetben is, ha ténylegesen csupán egyetlen bűntett elkövetéséhez nyújtott segítséget - az összes többi bưnért is köteles felelni, amelyet azon idő alatt követnek el, míg ő bizonyíthatóan a társaság tagja volt." A korabeli reformkori szerzők közül Szokolay István, ${ }^{5}$ Schnierer Aladár ${ }^{6}$ és Fayer László ${ }^{7}$ foglalkoztak a bűnszövetség és a bủnbanda kérdésével.

$\mathrm{Az}$ 1843. évi javaslat ${ }^{8}$ részletesen szabályozta a bűnszövetség fogalmát, eszerint: „Midőn többen, valamely közösen célba vett bűntettnek egymás segítségével leendő végbevitelére, előre határozottan összeszövetkeznek, ha a célba vett bűntett csakugyan bevégeztetett, mindené szövetkező, ki a szövetkezésnek következtében a bűntettnek elkövetése előtt vagy azalatt vagy után arra együtt munkálkodott, vagy pedig azáltal, hogy a véghezvitelnél szándékosan megjelent, készséget az együtt munkálkodásra megmutatta, mint bűnszerző azon büntetés alá esik, melyet azon bűntett rendel a törvény, $s$ minél nagyobb volt a befolyása a szövetkezek elhatározása, minél több részt vett a bűntettnek elkövetésében, a beszámítás reá nézve annál súlyosabb leen.” Az 1878. évi V. Csemegi-kódex ${ }^{9}$ a szövetség fogalmát az előkészület sajátos formájának tekintette, de kizárólag felségsértés, hútlenség vagy lázadás esetén rendelte büntetni. A 132. § szerint: „A szövetség létrejött, ha két vagy több személy a felségsértés elkövetését közösen egyetértéssel elhatározza."

A Hatályos Anyagi Büntetőjogi Szabályok Hivatalos Összeállítása 232. pontjának (2) bekezdése ${ }^{10}$ társadalmi tulajdon ellen irányuló bűntett elkövetése esetén halálbün-

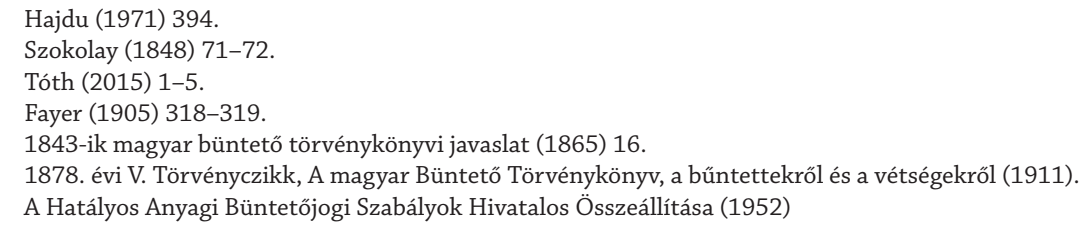


tetést is kilátásba helyezett, ha a cselekmény elkövetésében bűnszövetkezet kettő vagy több tagja vett részt.

A bűnszövetség mai fogalmának megalkotása az 1961. évi V. Büntető Törvénykönyvhöz ${ }^{11}$ kapcsolható. A 114. §-a szerint: „Bünszövetség akkor létesül, ha kettő vagy több személy büncselekményeket szervezetten követ el, vagy erre nézve megállapodik." A törvény miniszteri indokolása szerint a szövetség ott jelent minőségi ugrást a veszélyesség terén, ahol a tagok egyben magát a bűnözést szervezik meg, vagyis ismétlődően vagy éppen rendszeresen akarják folytatni bűnös tevékenységüket. ${ }^{12}$

Magyarországon az 1970-es évek második felében jelentkeztek a szervezettség első jelei. Katona Géza, ${ }^{13}$ Tauber István, ${ }^{14}$ Szabó András ${ }^{15}$ és Dános Valér ${ }^{16}$ tanulmányai szerint bővültek a lakosság bevételi forrásai, felgyorsult a kiskereskedelmi forgalom. Változás következett be a bűnözés struktúrájában, különösen a lakásbetörések szervezettsége erősödött. A megváltozott társadalmi és gazdasági viszonyok a kiemelkedően nagy hasznot biztosító bűnöző társulások megalakulását elősegítette.

\section{A büntetőjogi szabályozás kérdései a rendszerváltást követően}

Az 1990-es éveket továbbra is a bünözés nagyarányú emelkedése jellemezte. Katona Géza ${ }^{17}$ vizsgálatai szerint megjelentek az „olajügyek”, a gépjármúlopások, a kábítószerkereskedelem, az embercsempészet. ${ }^{18}$ A rendszerint magas fokú szervezettséget, múszaki felkészültséget és pénzügyi eszközöket igénylő hamisítással elkövetett bűncselekmények száma is nagy arányban emelkedett, például a pénzhamisítás. ${ }^{19} \mathrm{~A}$ szocialista országokban olyan korábban ismeretlen gazdasági bűncselekmények kezdtek kibontakozni, mint a deviza- és a vámbűncselekmények, illetőleg az adó- és társadalombiztosítási csalás. ${ }^{20}$ Megszületett a gazdasági társaságokról szóló 1988. évi VI. és a gazdasági társaságok átalakulásáról rendelkező 1989. évi XIII. törvény. ${ }^{21} \mathrm{~A}$ megkezdett privatizáció lehetőséget nyújtott a büncselekmények elkövetésére. ${ }^{22}$ A szervezettebb elkövetési formát mutató elkövetők jellemzően karrierbûnözők lettek és egzisztenciájuk alapja a folyamatos kriminalitás lett. ${ }^{23}$ A szervezett bünözés körvonalainak határozottabb kialakulását előmozdították a hazánkban megjelent külföldi bűnözők is. ${ }^{24}$

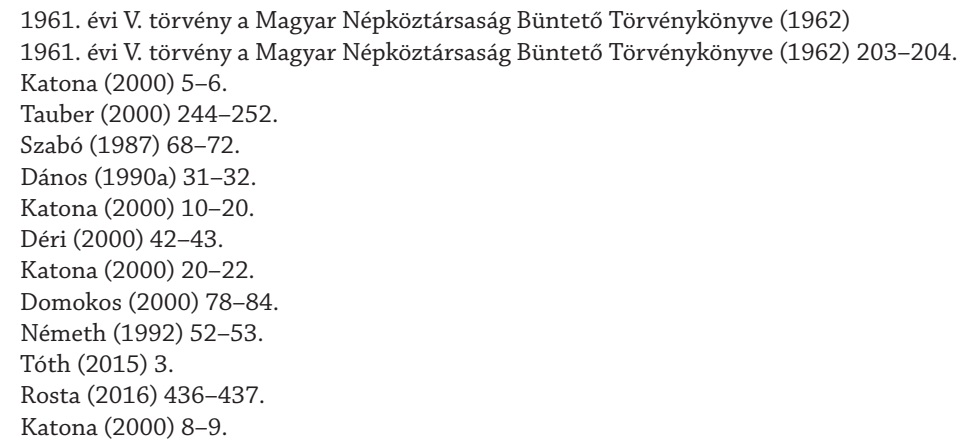


A Legfelsőbb Bíróság 1995. februári 154. számú Büntető Kollégiumi állásfoglalása ${ }^{25}$ hozott újabb változásokat: „A társas bűnelkövetés sajátos formája a szervezett bűnözés. E bűnelkövetési mód kiemelkedő veszélyessége miatt nyomatékos súlyosító körülmény, ha az ügyben a szervezett bűnözés ismérveit lehet megállapítani és az elkövető olyan részeként hajtotta végre a bűncselekményt." Ezt követően a szervezett bűnözés tételes jogi szabályozása 1997 és 2001 között több lépcsőben történt. Az 1997. évi LXXIII. törvény ${ }^{26}$ volt az, amely elsőként szabályozta a magyar jogrendszerben a bủnszervezet fogalmát: „[B]üncselekmények folyamatos elkövetésére létrejött olyan - munkamegosztáson alapuló - bűnszövetség, amelynek célja a rendszeres haszonszerzés.” A törvényhozó a meghatározó jegyeket emelte ki a fogalom megalkotásakor, így a munkamegosztást, a rendszeres haszonszerzést, azaz az üzletszerű és folyamatos elkövetést. ${ }^{27}$

Az Európai Unió Tanácsa 1998. december 21-én együttes fellépést fogadott el az Európai Unió tagállamaiban a bűnöző szervezetben való részvétel bűncselekménynyé nyilvánításáról. ${ }^{28} \mathrm{Az}$ együttes fellépés 1 . cikke határozta meg a bűnöző szervezet, míg 2. cikke a szervezett búnözői csoport fogalmát. A 2282/2000. (XI. 29.) Kormányhatározat ${ }^{29}$ alapján a belügyminiszter aláírta az ENSZ keretében létrejött egyezményt a határon átnyúló szervezett bűnözés ellen. Ezért újabb lépést jelentett a bűnszervezet fogalmát illetően az 1998. évi LXXXVII. törvény, ${ }^{30}$ miszerint bünszervezet: „[A] bűncselekmények rendszeres elkövetése révén, haszonszerzés végett létrejött olyan bűnszövetség, amely feladatmegosztáson, alá-felé rendeltségi rendszeren és személyi kapcsolatokon nyugvó szerepvállaláson alapul.” Érdemi eltérés a folyamatos és a rendszeres elkövetés volt. Új elemként lépett be az alá-fölé rendeltség és a személyi kapcsolatokon nyugvó szerepvállalás, amelynél a szervezettséget és a hierarchiát kívánták nyomatékosítani. ${ }^{31}$ Máig hatályos szabályozást teremtett a 2001. évi CXXI. törvény, ${ }^{32}$ miszerint a „búnszervezet három vagy több személyből álló, hosszabb időre szervezett összehangoltan müködő csoport, amelynek célja ötévi vagy ezt meghaladó szabadságvesztéssel büntetendő szándékos bűncselekmények elkövetése”. A törvény célja egyértelműen a szervezett gazdasági bűnözés elleni hatékony fellépés volt. ${ }^{33}$ A gyakorlatban mind a bűnszövetség, mind a bűnszervezet fogalmának értelmezésében nagy segítséget nyújtott a Legfelsőbb Bíróság IV. számú Büntető Elvi Döntése. ${ }^{34}$ A módosítást jelentősen befolyásolta az ország jogharmonizációs kötelessége a 2000. december 14-én Palermóban aláírt, az Egyesült Nemzetek Szervezete keretében lét-

\footnotetext{
A hatályos Büntető anyagi jogszabályok és a vonatkozó Alkotmánybírósági és Legfelsőbb Bírósági iránymutatások gyüjteménye (1999).

1997. évi LXXIII. törvény.

Búzás-Nagy (1999) 47-53.

Bezsenyi (2015)

2282/2000. (XI. 29.) Korm. határozat.

1998. évi LXXXVII. törvény 35. §.

Tóth (2015) 4-5.

2001. évi CXXI. törvény.

Gellér (2004) 29-30.

A hatályos Büntető anyagi jogszabályok és a vonatkozó Alkotmánybírósági és Legfelsőbb Bírósági iránymutatások gyüjteménye (1999)
} 
rejött egyezmény, a határokon átnyúló szervezett bủnözés ellen. Az egyezmény értelmében: „[O]lyan bűnözői csoportról van szó, amely legalább három főből áll, e bűnözői csoport hosszabb időre szerveződött, e bűnözői csoport összehangoltan múködik, e bűnözői csoport létének meghatározott célja van, e cél nem más, mint olyan szándékos bűnösségű bűncselekmények elkövetése, melynek büntetési tétele legalább 5 évi szabadságvesztés." ${ }^{35}$

Uniós csatlakozásunk előtt Finszter Géza és Irk Ferenc ${ }^{36}$ tekintette át térségünk szervezett bünözését. Véleményük szerint ennek célja az extra profit megszerzése, amelynek érdekében a szervezet nem válogat az igénybe vett eszközökben. Nagyfokú látencia és konspiráltság jellemzi, amelyet szigorú alá-fölé rendeltségi viszonyok konzerválnak. Az egyes bűnözői csoportok elkülönülten, egy-egy meghatározott területen, meghatározott árukörrel, büncselekményfajtával foglalkoznak, ugyanakkor a tevékenységi kör egyes szálai az egész országra kiterjednek. ${ }^{37} \mathrm{Az}$ ORFK Bűnügyi Főigazgatósága szerint hazánkban 2005-ben mintegy 50 bűnözői csoport és azok több alcsoportja tevékenykedett. A szerveződések alapja anyagi indíttatású volt. A tagjai túlnyomórészt magyar állampolgárok voltak, de erősödött az orosz, délszláv, arab, török, svájci csoportok alkotta szervezett bünözés száma is. ${ }^{38}$

\section{A hatályos szabályozás sajátosságai}

A 2012. évi C. törvény (továbbiakban: Btk.) ${ }^{39}$ a bűnszervezet fogalmát az értelmező rendelkezések között, a 459. § (1) bekezdés 1. pontjában határozza meg. E fogalmat a Magyarország 2020. évi központi költségvetésének megalapozásáról szóló 2019. évi LXVI. törvény módosította. Az új definíció szerint: a bűnszervezet legalább három személyből álló, hosszabb időre, hierarchikusan szervezett, konspiratívan múködő csoport, amelynek célja ötévi vagy ezt meghaladó szabadságvesztéssel büntetendő szándékos bűncselekmények elkövetése. Szükségesnek tartom megjegyezni, hogy a hatályos szabályozást illetően a bűnszervezet megjelenése az utóbbi időben hangsúlyossá vált a kábítószerrel visszaélés, valamint a költségvetési csalás körében, illetve különböző nemzetközi tendenciák alapján a migrációhoz kapcsolódóan az embercsempészés, valamint az emberkereskedelem tényállásaihoz kapcsolódóan, de más területeken, mint például a csúcstechnológiai bünözés terén is.

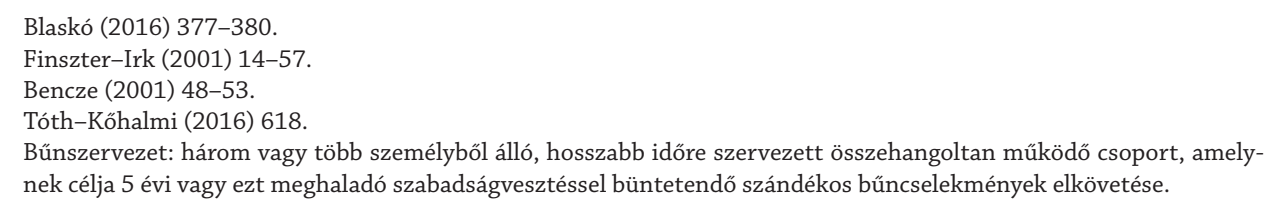




\section{A szervezett bünözés fogalommeghatározásának kérdései}

A szervezett bűnözés kifejezés két évtizede olyan fogalom volt, amely kizárólag az ÉszakAmerikában múködő szicíliai-amerikai csoportok leírására volt alkalmas. Mint már említésre került, hazánkban az 1970-es évek végén a nagy betörési hullám irányította rá a figyelmet a bandák szerkezetében megfigyelhető jellegzetességekre. Innentől kezdve hosszas vita indult meg a fogalomalkotás körül. A szervezett bűnözés fogalma minden országban eltérő, amelynek igazodnia kell az adott ország alkotmányos elveihez, ugyanakkor szükséges, hogy rugalmas is legyen, hiszen csak így követheti a szervezett bűnözés dinamikáját. ${ }^{40}$ Dános Valér ${ }^{41}$ akként foglalt állást, hogy a szervezett bűnözés társulásos, foglalkozásként űzött hivatásos vagyonszerző, egzisztenciateremtő hatású bûnözési forma, amely munkamegosztáson alapul, magas fokú konspiráció mellett valósul meg, és behatol a legális vállalkozásokba, esetenként a közhatalomba is. Borai Ákos ${ }^{42}$ szerint: „[A] szervezett bűnözés az adott társadalom összbűnözésének része, alapstruktúrája, a bűnözés különös szintű szelvénye, amelyeket azoknak a hivatásos bűnözőknek a bűncselekményei képeznek, akik valamely bủnöző társulás tagjaként követnek el tervszerúen, súlyos büncselekményeket erőszak ${ }^{43}$ vagy más megfélemlítésére alkalmas eszköz igénybevételével." Buzás Huba, illetve Nagy Sándor ${ }^{44}$ véleménye szerint: „[A] szervezet olyan intelligens rendszert alkotó struktúra, amely a munkamegosztás produktumaként valamely cél által előírt eredmény érdekében a feladatok differenciáltabb és integráltabb ellátása végett emberek szervezett közösségének normák által szabályozott formáját ölti és mint ilyen, egymással kölcsönhatásba lépő alkotóelemekből, viszonyokból és folyamatokból áll." Szabó Géza ${ }^{45}$ álláspontja pedig az, hogy: „[A] szervezett bűnözés olyan hatalom - vagy haszonszerzési célzatú, összességükben vagy önmagukban is kiemelkedő jelentőségű bűncselekmények tervszerű végrehajtása, amelyek elkövetésében több személy vesz részt, akik hosszú ideig múködnek együtt munkamegosztással, és kiterjedt - nemzetközi - kapcsolatokat tartanak fenn más bűnöző szervezetekkel."

A nemzetközi bűnözés (például körhintacsalás, árucsempészet) kategóriáin kívül is jellemző a bűnszervezetekre, az úgynevezett polikriminalitás. Ebből következik, hogy a csoportok tevékenysége jelentős arányban csak nemzetközi szinten értelmezhető, hiszen abban gyakran több ország egyszerre érintett. A bűnszervezetek több országban, több alaptevékenységet, illetve kiegészítő tevékenységet végezhetnek. Az alaptevékenységekből származó bűnös bevétel tisztára mosása pedig lehetséges egy har-

\footnotetext{
Bócz (2008) 6.

1 Dános (1990b) 25-26.

42 Borai (1992) 13.

43 Meg kell jegyezni, hogy az utóbbi évek európai szervezett bűnözését az erőszakkerülés jellemzi, mert az felkelti a bűnüldöző hatóságok figyelmét, amiben ellenérdekeltek a bünszervezetek. Ha ultima ratioként alkalmaznak is erőszakot, azt inkább saját tagjaikkal szemben teszik. Vö. European Union Serious Organised Crime Threat Assessment 2017. Crime in the age of technology (2017) 16.

44 Búzás-Nagy (1998) 203.

45 Szabó (1999) 49-50.
} 
madik országban olyan helyen is, ahol sem alap-, sem kiegészítő tevékenységet nem valósítanak meg. A legális gazdaságba történő befektetés pedig mindezektől függetlenül, egy újabb országban is történhet. A jelenségre az Europol már 2004-ben felhívta a figyelmet, és a legfrissebb SOCTA-jelentés 2017-ben publikált nyílt változata szerint az Európai Unió területén aktív bűnszervezetek 45\%-ára, azaz 2250 szervezetre igaz a polikriminalitás. ${ }^{46}$

\section{A bứnszervezet múködési sajátosságai, a rendszerváltást követően született jogesetek tükrében}

Hazánkban az eddigi nyomozások eredményeképpen felfedésre kerültek bűnszervezetek. Annak vezetői, tagjai bíróság előtt felelősségre lettek vonva. A médiából legismertebb a „fekete sereg” vezetője, Magyar Róbert és a szervezet tagjai, míg a Marian Cosma-ügyből Sztojka Iván mint vezető és a szervezetének tagjai. Budapesten több szórakozóhely működtetésével és rendőrök megvesztegetésével, utcai leszámolásokkal kapcsolatban merült fel Prisztás József, Portik Tamás és Vizoviczki László neve. Nyilvánvalóan az ügyeket felgöngyölítő nyomozók részletesen megismerték e bűnszervezetek létét, vezetőit, tagjait, azok mindennapi életét. Ennek ellenére álláspontom szerint kicsiny hazánkban oly mély társadalmi gyökerekkel rendelkező bűnszervezet, mint amelyek Dél-Olaszországban, Amerikában és Kínában kialakultak, több évszázados bűnözésre tekintenek vissza, nem alakultak ki. E bűnözőcsoportokat a nyugat-európai szervezett bűnözéshez, észak-amerikai gengszterizmussal vagy éppen dél-amerikai, esetleg távol-keleti bűnözéssel egybevetni helytelen lenne. ${ }^{47}$ Teljesen egyetértek Borai Ákos megállapításával, miszerint nem lebecsülendő a hazai szervezett bűnözés sem, de oly markánsan, mint ahogy az Nyugat-Európában, Dél-Amerikában, Kínában megjelenik, hazánkban nem. A bíróság elé került ügyek ismeretében véleményem az, hogy a bűnszervezet vezetői, tagjai önös anyagi érdekeik végett szerveződnek össze, céljuk kizárólagosan saját anyagi jómódjuk megteremtése azáltal, hogy területet foglalnak, majd azt védelmezve és a rendszeres bűncselekmények elkövetése révén a saját profitjuk megteremtésére törekednek. Nincsenek meg a szoros családi kapcsolatok, a lebukás veszélye esetén egymást nem védelmezik, nem törekednek a büntetőeljárás meghiúsítására, csupán annak elhúzására. A büntetőeljárás során széles körű bizonyítást kell lefolytatni annak érdekében, hogy a hatályos Btk. 459. § (1) bekezdés 1.) pontjában meghatározott bűnszervezet fogalom bizonyítást vagy megcáfolást nyerhessen. A Legfelsőbb Bíróság egyik ügyében az alábbi iránymutatást adta ezzel kapcsolatban: „[E] fogalmat a valódi tartalma szerint kell kezelni, mert az ennyi és nem több. Nem arról van szó, hogy e fogalmat elnagyoltan és sommásan szabályozták, hanem arról, hogy a bűncselekmény bủnszervezetben elkövetésének megállapításához a törvényi követelményeken túlmenő többletkövetelmény nem szükséges. A fogalmi ismérvek törvényi

\footnotetext{
46 European Union Serious Organised Crime Threat Assessment 2017 (2017); European Union Organised Crime Report 2004 (2004)

47 Borai (1992) 13.
} 
meghatározása kimerítő, azok más ismérvekkel nem bővíthetők. Egyértelmű a csoport minimális létszámának meghatározottsága, szervezettsége, összehangolt működése lényegileg ténykérdés, míg a szervezett múködés hosszabb időtartamára és a csoport céljára a tényállás értékelésével lehetséges következtetést levonni." ${ }^{48} \mathrm{~A}$ fentieknek megfelelően lássuk, mit takarnak a tényállási elemek.

A Büntető Törvénykönyvben megfogalmazott minimális három fővel múködő szervezet viszonylag ritka. Nagyobb létszámú szervezetek is viszonylag szúk, stabil maggal és sokszor változó összetételű külső résztvevők bevonásával tevékenykednek. Méretre legalább akkorák legyenek, hogy az összetettebb munkamegosztásból következő funkciókat az elkövetők elláthassák. ${ }^{49}$ A Legfelsőbb Bíróság szerint az elkövetésben részt vevő személyek számából, az elkövetés konspiratív körülményeiből, a célszerű feladatmegosztásból, az elkövetői kör hierarchikus felépítéséből, a bűncselekmény elkövetésében részt vevő vádlottnak tudnia kell, hogy bűnszervezet tagjaként vesz részt a büncselekmény elkövetésében. ${ }^{50}$

A szervezet tagjainak életútját tartós vagy ismétlődő bűnelkövetés jellemzi. ${ }^{51}$ A bűnszervezetek tevékenységének alapja a hosszabb időre szóló együttmúködés, amely strukturált feladatmeghatározást és célorientáltságot feltételez. A célok határozzák meg a szervezet fennállásának idejét, az összetételét és nagyságát. A bíróság azt állapította meg, hogy a vádlottak a fegyvercsempészés révén olyan nagy mennyiségú lőfegyver birtokába jutottak, amellyel kapcsolatban csak arra lehet következtetni, ezeket a fegyvereket további bűncselekmények elkövetéséhez kívánták felhasználni, saját tevékenységük körében. A hosszabb idő fogalmára tekintettel, nemcsak a már elkövetett bűncselekményeket kell értékelni, hanem a jövőben elkövetni szándékolt büncselekményeket is. ${ }^{52}$

A bűnszervezet szervezettségének fokát a feladattervezés mértéke szabja meg. A célok meghatározása és azok megvalósítása történhet egy állandó merev program szerint, amely előre rögzíti az eredmény eléréséhez vezető részcselekmény-mozzanatokat. Múködhet azonban hosszabb távú, de rugalmas program szerint is, amely alkalmazkodik a belső és külső környezeti hatásokhoz, és rövid időn belül aktualizálja azt a célhalmazból kiválasztott célt, amelynek megvalósítása biztosítja a bűnszervezet eredményes müködését. ${ }^{53}$

A csoportok legjellemzőbb ismérve a hierarchikus szervezettség, amely egy bűnözőcsoport sajátos kapcsolatrendszerének mikéntjét jelenti. Személyi kapcsolaton, aláfölé rendeltségi viszonyon alapszik. A tényleges elkövető egy egész szervezet súlyát, erejét tudja maga mögött, és ez még inkább bátorítja, de fenyegető is lehet rá nézve abban az esetben, ha a szervezettel szembefordulna. ${ }^{54}$

\footnotetext{
8 BH.2008. 139.

9 Búzás-Nagy (1999) 54.

BH.2009. 96.

51 Dános (1990b) 27-28.

2 BH.2008. 139.

53 Tóth (2009) 20-23.

54 Bócz (2001) 6.
} 
E szervezetben a bűnelkövetők három szintjét különböztetjük meg: főnöki szint, amelynek tagjai már elpolgárosodtak, a társadalom mintaszerú tagjaivá váltak, a menedzsment szint, amely közvetít a szintek között, az akció szint, amely bűncselekményfajták és egyéb érdekek szerint szerveződik. Idetartoznak nemcsak a közkatonák, de a specialisták is. Kapcsolódhatnak még legális fedőszervezetek, mint jogászok, orvosok, közgazdászok, adószakértők, újságírók és egyéb más tanácsadók is. ${ }^{55} \mathrm{~A}$ bíróság szerint a 2004-ben I. r. vádlott által irányított bünszervezet vezetésébe tartoztak II., III., IV., V. r. vádlottak, míg további tagjai VI., VII., VIII. r. vádlottak voltak, valamint az eljárás során nem azonosítható további személyek. II-V. r. vádlottak VI-VIII. r. vádlottakkal napi kapcsolatban álltak, irányították őket a fegyvercsempészet végrehajtása során. VI-VIII. r. vádlottak pedig vezették az alájuk tartozó további tagokat. ${ }^{56}$ Ezen öszszehangoltság meglétének tehát nem feltétele a bűnszervezetben valamennyi cselekvő egymással való közvetlen kapcsolata. ${ }^{57}$

Hierarchikus az a rendszer, amely egymással kölcsönös kapcsolatban álló alrendszerekből áll. A főnöki szint végzi az információszerzést, elemzést, tervezést, döntést, utasításadást, szervezést, koordinációt, ellenőrzést. A menedzsment a kapott utasítások alapján a konkrét vezetés-irányítási teendőket látja el. Gondoskodik a feladatok végrehajtásának folyamatáról, majd az információk visszacsatolásáról. Az akció szint a közvetlenül vezérelt bűnelkövetési folyamatokat szervezi és irányítja. ${ }^{58} \mathrm{Az}$ egyes szintek és feladatkörök bár mereven nem válnak el egymástól, egyes szinteken lévő tagok, résztvevők más feladatkörökbe is bekapcsolódhatnak. A tényállás szerint 2002. decemberben I. r. vádlott megbízta a személyszállítással foglalkozó II. r. vádlottat afrikai országokból származó 15 személynek anyagi ellenszolgáltatás fejében történő Olaszországba juttatásával. III. r. vádlott szervezte meg a migránsok pihentetését, szállításukat IV. és V. r. vádlottak végezték. Az útvonalat VI-VIII. r. vádlottak biztosították, akik mobiltelefonon tartották a kapcsolatot a szállítókkal és V. r. vádlottal. A szállítás közben IX. r. vádlott előfutói feladatokat végzett. Az osztrák-magyar határ gyalogosátlépését X. r. vádlott vezette, majd a migránsokat XI. r. vádlott útvonal-biztosítása mellett hamis osztrák rendszámú gépkocsival XII. r. vádlott Olaszország felé szállította. ${ }^{59}$

A szervezett bűnözés munkamegosztáson alapuló magas fokú konspiráció mellett megvalósuló bűnözési forma. Munkamegosztás a bűnszervezet szervezeti egységei és tagjai között a feladatok célszerű felosztását jelenti. ${ }^{60} \mathrm{~A}$ bűnözői körben a résztvevők feladatai jól elhatárolhatóak egymástól, együttmúködésük alapja kifinomult, sajátos kommunikációs rendszer. Konspiráció azt biztosítja, hogy a csoportok tagjai egymást csak a szükséges és elengedhetetlen mértékig ismerjék, a szervezeten belüli szerepeket pontosan, árnyaltan elosszák. ${ }^{61}$

\footnotetext{
Búzás-Nagy (1999) 204.

BH.2008. 139 .

BH.2009. 96.

8 Búzás-Nagy (1999) 53-54.

9 BH.2009. 96.

0 Búzás-Nagy (1999) 53.

61 Dános (1990b) 32.
} 
A csoportba kerülés és a közreműködés döntő mozzanata a feladatra való alkalmasság és a készség a személyes szolidaritásra, hűségre való hajlam. Társakat a büntetésvégrehajtási intézetben is lehet toborozni. Hasonlóan érvényesül e tendencia a fiatalkorúak zárt jellegű nevelőintézeteiben is. ${ }^{62}$ A hosszú távra tervező bủnszervezetek a bűnözésre tehetséges fiatalokat úgymond „beiskolázzák”, mint a rendőri tagintézményekben, hogy később pozícióba jutva hasznuk legyen belőle. ${ }^{63}$ A szegénység és a korlátozott lehetőségek önmagukban még nem jelentenek nagyobb arányú normaszegést, viszont kétségtelenül jobban hajlamosítanak erre, mint a kedvező társadalmi körülmények. ${ }^{64}$

A szervezett bűnözés elsődleges célja a vagyonszerzés. A bűnözést hivatásosan, a bưncselekményt anyagi haszonszerzés céljából követik el. ${ }^{65} \mathrm{~A}$ tényállás értelmében I. $\mathrm{r}$. vádlott 2013. decemberben az embercsempészet bûncselekményének elkövetésébe komoly jövedelemszerzési lehetőséget ígérve beszervezte ismerőseit, így V., VI. r. terhelteket is a szállítói feladatok ellátására. A fent részletezettek szerint került sor a különböző származású migráns személyek Magyarországon történő külföldre juttatására. A bíróság szerint üzletszerű elkövetés folytán törekedtek rendszeres haszonszerzésre. Ez a bűnelkövetés vonatkozásában egy folyamatot jelent, ami pedig feltételezi a szervezet tartós, hosszabb időn át való működését. ${ }^{66}$

A szervezett bűnözés ennélfogva egzisztenciateremtő hatású bűnözési forma, ahol a bűnözés produkcióját a folyamatosság és a rendszeresség reprezentálja. Az érintett elkövetőknek magas életnívót, luxus életkörülményeket, nagyvilágiságot biztosít. ${ }^{67}$

Ugyanakkor a szervezett bűnözők cselekményei nemcsak egyszerűen haszonszerzésre irányulnak, hanem gazdasági jellegű profitra, adott esetben a hatalom megszerzésére. ${ }^{68} \mathrm{~A}$ szervezett bűnözés a legális vállalkozásba behatoló bűnözési forma. A bűnöző csoport hosszabb múködésének legszükségesebb feltétele, hogy legalizálni lehessen a bűnös úton megszerzett pénzt vagy vagyontárgyat. Ehhez olyan legális vállalkozásra van szükség, ahol a bünös pénzt tisztára lehet mosni. ${ }^{69} \mathrm{~A}$ társadalmat fenyegetô igazi veszély, hogy a feketegazdaságból származó tőkevagyonok beépülnek a legális gazdaságba. Gazdasági társaságok és a pénzintézetek részvételével mossák tisztára a bűncselekmények elkövetése útján szerzett tőkét, fantomcégek létesítésével tüntetik el a hozzájuk vezető nyomokat. Az illegálisan szerzett, majd legalizált vagyonok hatalmával a bünszervezet megkísérli a behatolást a politikába, a gazdasági lobbikba, a közigazgatás, a rendőrség szervezeteibe, a bírói hatalomba. ${ }^{70} \mathrm{~A}$ vagyonszerzés a szervezett bűnözés legfőbb célja, de a szervezetek által elkövetett más bűncselekmények miatt,

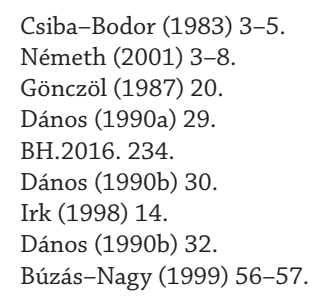


az alapvető három kategóriába sorolható tevékenységük iránya: az élet, testi épség, személyi szabadság elleni bűncselekmények, a vagyon elleni és gazdasági bűncselekmények, és személyek, áruk, szolgáltatások tiltott forgalmával, kereskedelmével kapcsolatos bűncselekmények. Az első csoportba jellemzően leszámolási céllal elkövetett emberölések, testi sértések, emberrablások tartoznak. A másodikba lakásmaffia, ${ }^{71}$ gépjármü-, múkincslopások, zsarolások, csalások, termékhamisítások, pénz- és értékpapír-hamisítások, pénzmosások. A harmadik csoportba ember- és szervkereskedelem, migránsok csempészése, kábítószer-kereskedelem, fegyverkereskedelem, nukleáris és radioaktív anyagok, védett növény- és állatfajok forgalmazása. ${ }^{72}$

\section{Búnszervezeti kérdések a költségvetési csalással érintett ügyekben}

A szervezett bűnözés a gazdasági életben jellegzetesen egy-egy árukörrel, főleg a magas adótartalmú termékekkel kapcsolatban, továbbá a jogosulatlan adó-visszaigénylések megszerzése kapcsán jött létre. Az elkövetők magas jövedelemmel, nagy mozgatható tőkével rendelkező rétegből jönnek, rájuk jellemző a nagyfokú szervezettség, magas technikai színvonal. Ez a réteg a legális tevékenységgel elérhetőnél lényegesen magasabb profit érdekében követ el bűncselekményeket. Az illegális tevékenységgel szerzett hasznot visszaforgatják, újabb bűncselekmények elkövetésére fordítják. A bűnelkövetői kör elsősorban a jövedéki termékekre elkövetett bűncselekményeknél élesen kettéosztható az értelmiség, magasan kvalifikált vezető, irányító rétegre, illetve a végrehajtókra, akiknek a személyi összetétele vegyes, magában foglalja más büncselekmények elkövetésére specializálódott bűnelkövetők körét is. A felderítést az irányító réteg nehezíti meg, esetenként lehetetlenné is teszi, ugyanis szakemberekkel veszik körül magukat, személyi és technikai felszereltségük messze túlmutat a nyomozóhatóságén. Az irányító réteg olyan személyeket használ fel végrehajtóként, akik anyagi egzisztenciájuk, szakirányú ismereteik, iskolai végzettségük alapján nem kezdhettek volna nagyszabású vállalkozásba, amely révén bűncselekményeket elkövethették volna. A büntetőeljárások azonban elsősorban a végrehajtói kör tagjai ellen indulnak, ők azonban semmilyen információval nem tudnak szolgálni, mivel csak részfeladatokat teljesítettek. A szervezetten elkövetett gazdasági bűncselekmények sok esetben nemcsak egy város vagy megye területére korlátozódnak, hanem behálózzák az ország egész területét. Különösen igaz ez a magas adótartalmú termékekkel vagy az olajügyekkel kapcsolatban. A bűncselekményeket döntően gazdasági társaságok keretében valósítják meg. Az illegális tevékenység leplezésére létező, de az adott termék forgalmazásával nem foglalkozó, esetlegesen nem is létező gazdasági társaságokat szerepeltetnek eladóként vagy vevőként a forgalmazást alátámasztó számlákon. ${ }^{73} \mathrm{~A}$ bủnös úton megszerzett vagyon legalizálása napjaink egyik legveszélyesebb jelenségévé vált, amely

\footnotetext{
Madai (2011) 224-228.

Tóth-Kőhalmi (2016) 615-616.

73 Szőcs (2000) 221-225.
} 
bizonyos szervezettséget feltételez. Már nem csupán veszély, kézzel fogható realitás, hogy a feketegazdaságból származó tőkevagyonok fokozatosan beszivárognak a legális gazdaságba. A modern bűnszervezetek sokszor látszólag tekintélyes gazdasági társaságok, neves pénzügyi szolgáltatók segítségével mossák tisztára a bűncselekmények elkövetése útján szerzett tőkét, gyakran fantomcégek létesítésével tüntetik el a hozzájuk vezető nyomokat. ${ }^{74}$

A fentiekben részletezettek szerint napjaink bírói gyakorlatában kívánom bemutatni, hogy a szervezett bűnözés és a költségvetési csalás milyen szorosan összekapcsolódik. Nem új keletű, hogy a szervezett bűnözői csoportok számos bủncselekményt követtek el a '70-es évek óta a magas adóval terhelt termékekre, szolgáltatásokra nézve, hogy ezáltal jogosulatlanul igényeljenek vissza elsősorban általános forgalmi adót. Álláspontom szerint a 2012-es évektől kezd megjelenni a bíróságok gyakorlatában a költségvetési csalás bűntettei esetében, a társas bűnelkövetési magatartásokon túlmutató szervezett elkövetési mód. 2006-2007 évektől a vádlottak olyan gazdasági láncolatokat építettek ki az áruk adásvétele folytán, amelybe fiktív, vagyis valós gazdasági tevékenységet nem folytató hazai, illetve uniós tagállami cégeket is bevettek. E társaságok a fiktív számlák kiállítása után elérhetetlenek voltak a hatóságok felé, nyilvánvalóan bevallási kötelezettségüknek sem tettek eleget. E láncolat önmagában több szereplőt követelt meg. Egyetértve Tóth Mihály és Szőcs László gondolataival, csak a szervezet vezetője volt birtokában annak a tudásnak és szakképzett adminisztrátori, könyvelő személyzetnek, amelyet anyagilag támogatva képes volt egy több szereplős láncolatot müködtetni, olyan elkövető társakat összefogni, akik alacsony képzettségük folytán, kizárólag a szervezet fejének utasításait követve végezték a rájuk szabott feladatot a szervezeten belül, hiszen kizárólag az anyagi ellenszolgáltatás motiválta őket. A hosszabb időre szervezettség és a kiállított számlák bruttó tartama alapján teljes mértékben tudatában voltak annak, hogy egy szervet tagjaiként követik el a bűncselekményt.

Arra nézve, hogy a bíróságokon költségvetési csalás bűntette miatt jogerősen elítéltek mekkora százaléka követte el cselekményét bűnszervezet keretén belül, statisztikai adatot bemutatni nem tudok. Az Országos Bírósági Hivatal Magyar Igazságügyi Akadémia Tudományszervezési és Dokumentációs Osztály tájékoztatása szerint, a kötelező adatszolgáltatásban a bűnszervezetben történő elkövetés nem szerepel. ${ }^{75}$

Emellett 2013-2018 között 30 ügyet vizsgáltam meg az alábbi szempontok szerint: ${ }^{76}$ az ügyészség vádemelési gyakorlata, az elkövetett bűncselekmény jellege, a fentiekben bemutatott szervezeti működési modell megvalósulása.

Az ügyészség vádemelési gyakorlatában egyre inkább megjelennek azon elemek, miszerint a társas és csoportos elkövetési formákon kívül, a vádlottak cselekményét bűnszövetségben vagy bűnszervezetben elkövetettnek minősítik. Az ügyészség részé-

74 Tóth-Köhalmi (2016) 616.

75 Országos Bírósági Hivatal 2019. január 31. napján kelt tájékoztatása.

76 Empirikus kutatás 2013-2018. évekre a Debreceni Törvényszék, Fővárosi Törvényszék, Kecskeméti Törvényszék, Szegedi Törvényszék, Debreceni Ítélőtábla, Fővárosi Ítélőtábla, Szegedi Ítélőtábla ítéletei alapján. 
ről az előbb jelzett ügyekben olyan bizonyítékok beszerzésére került sor, amelyek szerint a vádlottak közötti telefonbeszélgetések túl rendszeresek, napi szintűek, amely kifejezetten a jogtalan haszonszerzés érdekében történik. A láncolat élén álló vezető vagy személyesen, vagy alárendelt személyek által fogja össze a számlázásban részt vevő gazdasági társaságok stróman, illetve valós gazdasági tevékenységet folytató ügyvezetőit. Nemcsak a telefonbeszélgetések, de a lefolytatott bizonyítási eljárás is hűen tükrözi a vezető és a tagok közötti hierarchikus, alá-fölé rendeltségi viszonyt.

Az elkövetett bűncselekmények egy típusba sorolhatók, vagyis a láncolatos áfacsalásba.

A tényállás szerint I., II., III., IV. r. vádlottak 2011-től 2013-ig cukorkereskedelmi ügyleteket bonyolítottak le oly módon, hogy az árut különböző gazdasági társaságok felhasználásával, főként az Európai Közösségen belülről nettó áron szerezték be, majd azt kis árréssel, az áfa beépítése nélkül, alacsony összegű számlákkal Magyarországon forgalomba hozták. A beszerzéseket I. r. vádlott vezetése alatt álló kft. magyarországi beszerzésként tüntette fel, amelynek alátámasztására II. r. vádlott befolyása alatt álló három kft. által kiállított valótlan tartalmú számlákat fogadott be. A cukor továbbértékesítése több láncolaton keresztül történt. A cukor az okmányokon feltüntetettektől eltérően, rövidebb úton jutott el a bűnszervezet személyi köréhez köthető gazdálkodók által üzemeltetett raktárig, ahonnan közvetlenül a kiskereskedelmet folytató gazdálkodókhoz került.

Ugyanilyen elkövetésről szól a következő tényállás: 2012-2013-ban I-IV. r. vádlottak kristálycukrot és étolajat szereztek be Szlovákiából, a valós gazdálkodó tevékenységet nem folytató, és befolyásuk alatt álló magyar honosságú gazdasági társaságok nevében. Ezt követően a szintén vezetésük alatt álló társaságok az árut belföldi megrendelőknek értékesítették tovább. Fiktív bizonylatokkal kívánták igazolni, hogy a közösségi árut a szlovák cégtől szerezték be, majd értékesítették tovább. I-IV. r. vádlottak vezetése alatt álló gazdasági társaságok könyvelésébe ráfordításként, költségként állították be a látszólagos tényleges kereskedelmi tevékenységet nem folytató cégek fiktív számlái annak érdekében, hogy az adófizetési kötelezettség mértékét látszólag csökkentsék, az adóterhet színlelt módon áthárítsák a számlázási láncolat alacsonyabb szintjén álló társaságokra.

Ugyanezt az üzleti modellt követték I., II. és III. r. vádlottak, akik 2007-2008 között múködtek együtt, és gazdasági láncolatot építettek ki. A kapcsolatrendszer nem alkalmi együttmúködés volt, tevékenységüket hosszabb időn keresztül tervezték folytatni. Minden vádlottnak megvolt I. r. vádlott által kiosztott és jól behatárolt feladata. A rendszert valamennyi vádlott társ által tudottan I. r. vádlott irányította akként, hogy a kft. gazdasági igényeinek megfelelően adta el a külföldi, illetve belföldi gyártóktól történő beszerzésekre vonatkozóan a megrendeléseket, biztosította azok anyagi hátterét, és részt vett a fuvarozás, raktározás megszervezésében is. Az I. r. vádlott utasításait a társai teljesítették. A II. és a III. r. vádlottak az utasításoknak megfelelően részt vettek a fiktív gazdasági láncolat részeként müködő gazdasági társaságok irányításában, múködtetésében, illetve a fiktív számlák kibocsátásában. 
A sort lehetne folytatni további hasonló elkövető magatartás bemutatásával, hiszen a vizsgált ügyek többségében ez az üzleti modell volt a jellemző.

A következő bűnszervezetet vezető I. r. vádlott célja az volt, hogy az érdekeltségébe tartozó vendéglátóipari tevékenységet folytató gazdasági társaságok bevételeinek egy részét az adóhatóság elől eltitkolja annak érdekében, hogy az általános forgalmi adó fizetési kötelezettségeket csökkentse, amellyel a költségvetésnek vagyoni hátrányt okozott. Erről és ennek módjáról előre megállapodott az irányítása alá tartozó II-X. r. vádlottakkal, akik részben az üzlethelyiségeket vezették, illetve könyvelték. E vádlottak, az I. r. vádlott utasítását továbbították a beosztottak felé. A résztvevők legálisan létrejött, jól szervezett gazdasági egységet használtak fel a büncselekmény elkövetéséhez, ahol a cselekmények elkövetését a meglévő struktúra szolgálta ki. Ezen belül a vezetői, a közbenső vezetői és a végrehajtói szinteket az I. r. vádlott állapította meg. A csoport tagjai rendszeresen találkoztak, és egyeztettek a bevétel eltitkolása érdekében a pénzkezelésre jogosult alkalmazottak elszámoltatásáról, továbbá a bevételnek a pénztárgépbe történő beütéséről.

$\mathrm{Az}$ általános forgalmi adó csalástól eltérően egyéb elkövetési módokra is akadt példa. Az I. r. vádlott által képviselt cég nagy értékű informatikai természetú állami közbeszerzést nyert el közigazgatási szerveknél. A projektekben szereplő szoftverfejlesztést és ahhoz kapcsolódó munkát kizárólag saját cége útján végezte, minthogy a szerződéskötéskor is azt a nyilatkozatot tette, alvállalkozót nem vesz igénybe. Ennek ellenére kilenc társaságnak mint alvállalkozóknak számláit csatolta, vagyis úgy tüntette fel, mintha a munkák jelentős részét alvállalkozókkal végeztette volna el. Az alvállalkozókkal kötött szerződések és számlák fiktívek voltak, minthogy megfelelő szakképzettséggel rendelkező alkalmazottakkal egyik társaság sem rendelkezett. Az I. r. vádlott célja kizárólag az volt, hogy a számlák alapján fizetendő forgalmi adó mértékét jogtalanul tudja csökkenteni.

Utolsó esetpéldaként kamionokban szállított áru fosztogatására szerveződött bűnbanda múködését mutatom be. Az interneten különböző cégek áruszállítmányok célba juttatására kerestek megfelelő fuvareszközzel rendelkező vállalkozókat. Ezekre a szállítmányokra jelentkezett be az I. r. vádlott által vezetett bünszervezet. Ennek érdekében elsőként a szervezet tagja, a III. r. vádlott feladata volt, hogy valós gazdasági tevékenységet nem folytató társaságokat alapítson, stróman ügyvezetőkkel. Ezután e társaságok nevében idegen nyelveket jól beszélő IV. és V. r. vádlottak jelentkeztek be az internetes felületeken, és vállalták fel az áruk szállítmányozását. Miután a fuvarozáshoz megfelelő eszközzel nem rendelkeztek, szándékukban sem állt a fuvarmegbízást ténylegesen teljesíteni. A megbízások megszerzését követően ezért azokat továbbították olyan jóhiszemü alvállalkozóknak, akik a szállításhoz már megfelelő eszközzel rendelkeztek. A megrendelőknek megadták ez utóbbi, általuk igénybe vett alvállalkozók fuvareszközeinek a forgalmi rendszámait, majd az alvállalkozók a felrakodás helyén megjelentek és elszállították az árut. A sofőrt menet közben közvetlenül tájékoztatták a megváltozott lerakodási helyről. Mindezen körülményekre figyelemmel a bűnszervezet részéről a valós szállítási szándék nem volt megállapítható, annak tagjai jogtalan haszonszerzés végett, a megrendelőket a valós szállítási szándék tekintetében tévedésbe ejtették, és ezzel nekik kárt okoztak. 


\section{Következtetések}

A fentiekben vizsgált ügyekben a bíróság elsőként a szervezet célját, felépítését, múködését vizsgálta. A vádlottak között mindig volt egy központi személy, az I. r. vádlott, aki a társait összefogva irányította a szervezetet és az annak keretén belül elkövetett bűncselekményeket. Ennek az I. r. vádlottnak célja kizárólagosan a jogtalan haszonszerzés volt, amelyet éveken keresztül kívánt folytatni, ezzel nemcsak saját magának, de a szervezet tagjainak is jólétet biztosítva. A lefoglalási jegyzőkönyvek alátámasztják, hogy a vádlottaktól legális bevételeiket jócskán meghaladó nagy értékű személygépjármúveket és ingatlanokat foglaltak le, amelyek megszerzésének forrása a bűncselekményből származó jövedelem volt. A szervezetek vezetőinek irányításával láncolatosan és összehangoltan múködő csoport tagjaként fiktív számlák kibocsátása és befogadása révén olyan tevékenységet folytattak, amely segítségével kizárólag I. r. vádlott által müködtetett gazdasági társaság adóügyi visszaéléseket tudott elkövetni. Az árufosztogatásra specializálódott szervezet bevételei értelemszerűen ebből a tevékenységből származtak, egyebekben tevékenységük hasonlított a láncolatos áfacsalást elkövetőkére.

Nincs jelentősége a tényállás és a felelősség megállapítása szempontjából, hogy az I. r. vádlott társaival pontosan mikor és hol állapodott meg a bűncselekmények elkövetésében. A lényeg az, hogy a tényállásban foglalt időszakban a konkrétan megjelölt vádlottak és cégek már e megállapodásnak megfelelően összehangoltan tevékenykedtek. A vádlottak ezt követően rendszeresen egyeztettek, személyesen, részben telefonon, a kommunikáció során nagyszámú telefonkészüléket használtak, a telefonszámokat folyamatosan cserélték. Az I. r. vádlott folyamatosan kapcsolatot tartott vádlott társai által képviselt cégekkel, az esetleges alvállalkozói csoport stróman ügyvezetőivel. A vezető a többi résztvevő tevékenységét koordinálta a szerződéskötésektől, a számlák kiállításán, ellenjegyzésén, a teljesítési igazolások aláírásán át, egészen a banki átutalásokig.

Nemcsak létszámuk alapján, hanem a vádlottak összehangolt magatartása alapján is megállapítható volt a vizsgált ügyekben a bűnszervezet keretein belül történt elkövetés. Az I. r. vádlott találta ki a szervezetet és az elkövetendő bűncselekményeket, azok kivitelezési módszerét. A szórakozóhelyek üzemeltetésével foglalkozó bűnszervezet vezetője maga állapította meg, hogy társai közül kik tartoznak a szervezet vezetői, közbenső vezetői és végrehajtói szintekhez. A munkamegosztást tökéletesen szemlélteti a fuvarokat felvállaló bűnszervezet. Itt a III. r. vádlott alapította a valós tevékenységet nem folytató cégeket, a fuvarokat IV. és V. r. vádlottak szervezték le, II. és VI. r. vádlottak gondoskodtak I. r. vádlott mobilitásáról, utasításainak továbbításáról és a megszerzett áru értékesítéséről. A lefolytatott bizonyítási eljárás alapján megállapítható, hogy I-VI. r. vádlottak, ha személy szerint nem is ismerték egymást, kölcsönösen nem tartották a kapcsolatot, de tudomással bírtak arról, hogy egy hosszabb időre létrehozott szervezetben súlyos bûncselekmények elkövetésében vesznek részt. Nem lehet kérdéses, hogy tisztában voltak az elkövetési értékkel, hiszen kamionnyi áruk jogtalan eltulajdonításáról volt szó. A valamennyi vizsgált üggyel kapcsolatban 
kijelenthető, hogy a vádlottak a bűncselekményekben pontosan felismerték a sorozatos elkövetést, az összehangoltságot és szervezett jelleget. A hosszabb időre tervezettségre következtetni lehet a szervezésből, amely a többszöri csalási és lopási cselekmények sikerét volt hivatott szolgálni. Valamennyi ügyben a vádlottak tudata átfogta, hogy bűnszervezet részesei. Közremüködtek a banki átutalásokban, kezükön nagy öszszegek folytak át. Már ezekből fakadóan is tisztában voltak azzal, hogy a kibocsátott fiktív számlák rendszeres adóügyi visszaéléseket szolgálnak. Részvételükkel múködő bưnszervezet a lehető leghosszabb ideig fog múködni, és ezalatt bármekkora összegú adóhiányt is okozhatnak a költségvetésnek, amely nemcsak a költségvetésre, hanem rájuk nézve is akár súlyos következményekkel járhat.

A védelem rendszerint arra hivatkozott, hogy saját védence csupán néhány büncselekmény elkövetésében vett részt, nem volt tudatában annak, hogy egy szervezet része. A bíróságok nem osztották a védelem álláspontját, ugyanis a fogalmi ismérvek törvényi meghatározása kimerítő, azok más ismérvekkel nem bővíthetők. Egyértelmű a csoport minimális létszámának meghatározottsága, szervezettsége, összehangolt múködése lényegileg ténykérdés. A szervezett múködés hosszabb időtartamára és a csoport céljára a tényállás értékelésével lehetséges következtetést levonni. A tényállások értelmében a bűnszervezet a megkívánt három taggal múködött, hosszabb időre átlagban 2-4 éven keresztül. A szórakozóhelyek müködtetésével foglalkozó bűnszervezet 3 főt jóval meghaladó személyből álló cégcsoport volt, múködését a jól szervezettség, összehangoltság jellemezte, a hosszabb időre szervezettség pedig nem lehet kétséges. A napi bevételeket, kiadásokat külön belső nyilvántartási, ellenőrzési rendszer működtetésével rendszeresen ellenőrizték. Cégszerű szervezettséggel és összehangoltan tették ezt úgy, hogy céljuk egyébként ötévi vagy ezt meghaladó szabadságvesztéssel büntetendő szándékos bűncselekmények elkövetése volt. Az összehangolt múködés tartalmát tekintve nem más, mint a benne cselekvő személyek egymást erősítő hatása. Ugyanakkor az öszszehangoltság meglétének nem feltétele a bűnszervezetben cselekvők közvetlen kapcsolata, más cselekvések, illetve a más cselekvők kilétének pontos ismerete. Az ügyekből megállapítható, hogy I. r. vádlott megteremtette a búnszervezetben cselekvők kapcsolatát, függetlenül attól, hogy más cselekvések, illetve más cselekvők kilétének megvolt-e a konkrét ismerete. Az alvállalkozók bevonása, tevékenységének irányítása és koordinálása, az általuk fiktív költségszámlák kiállítása, azoknak könyvelésbe, majd adóbevallásba beállítása, végül az adóbevallások benyújtása csak szükségszerúen szervezetten és összehangoltan történhet, akkor az a cégek részéről eljáró személyek bűnszervezetkénti múködését jelenti.

A szervezeteket - különösen a láncolatos áfacsalások esetében - adminisztratív és könyvelő apparátus is kiszolgálta. Közöttük voltak kereskedelmi ügyintézők, akik már kiépített kapcsolatrendszerrel rendelkeztek.

Vannak olyan esetek, amikor nem egy határozottan kirajzolódott hierarchikus szervezetről van szó, de azt a törvény nem is kívánja meg. Az ügyekből megismert vádlottak egymás barátai, rokonai voltak. Ahogy a tanulmány elején Katona Géza, Tóth Mihály fogalmaznak, e szervezetek életre hívója egy adott áru, szolgáltatás hiánya volt, 
de emellé tehetőek egyes áruk magas áfatartalma is. Ezt kívánták kihasználni, és ezzel magas haszonhoz jutni. Kétségtelen az I. r. vádlottak meghatározó szerepe, vádlott társaival a szervezet fennállása alatt megmaradt a szoros üzleti és baráti kapcsolata, amely biztosította a szervezet továbbélését. A hosszabb időre szervezettségükre következtetés vonható le a szervezeti felépítés viszonylagos állandóságából, illetve a tevékenységből is. Pár hónapos elkövetés alapján is megállapítható a bűnszervezetnél a hosszabb időre tervezett elkövetés még kisebb számú büncselekmények elkövetése esetén is. Jelen ügyekben viszont az elkövetés majd 2-4 évig tartott, és viszonylag nagyobb számú cselekmény elkövetésére került sor, amely szintén a bűnszervezeti elkövetést erősítette meg. Az általuk végrehajtott cselekmények elérték a szervezettség azon szintjét, amely a bủnszövetséget meghaladva már a bűnszervezeti elkövetés megállapítását indokolta.

\section{Záró gondolatok}

Elemzésemben megkíséreltem összefoglalni a bűnszervezet-fogalom kialakulásának egyes állomásait. A fogalom kialakulása szerves összhangban van a gyakorlati életben megjelenő jogalkalmazói problémákkal.

Ahogy már utaltam rá, kialakult és megszilárdult egy időtállónak tûnő bűnszervezetfogalom, amely a különös részi tényállásoktól függetlenül bizonyos kritériumok mellett a magyar Büntető Törvénykönyv általános részében került meghatározásra.

Az állandónak tűnő fogalommeghatározás mellett azonban vannak olyan jogesetek, amelyek arra intenek bennünket, hogy a fogalommeghatározás egyik elemét - 5 évi vagy azt meghaladó szabadságvesztéssel büntetendő cselekmény - ne tekintsük véglegesnek. Felvetődnek olyan konkrét ügyek, ahol a bűnszervezeti magatartáshoz alacsonyabb büntetési tételü, azonban ennek ellenére összességükben jelentős társadalomra veszélyességű cselekmények kapcsolódnak.

Ilyen esetek lehetnek például a költségvetési csalás különböző változatai, az egyéb gazdasági bűncselekmények, továbbá az egyes jövedéki tényállások, amelyek esetében a bűnszervezet ismérvei az alacsonyabb büntetési tétellel fenyegetett büncselekmények esetében is megállapíthatók.

Adott tehát a témában a továbbgondolás és továbbgondolkodás lehetősége.

$\mathrm{Az}$ általam áttekintett adócsalás és költségvetési csalás tárgyában a Debreceni Törvényszéken 2015-ig befejezett ügyekben nem merült fel a bünszervezeti társas bünelkövetési forma.

A klasszikus gyakorlat az volt, hogy egy gazdasági társaság fiktíven számlázó társaságoktól, amelyeknek ügyvezetői strómanok voltak, számlákat fogadott be. Ezáltal a számlabefogadó társaság, aki tudatában volt a számlák fiktív voltával, elkövette a költségvetési csalás bűntettét.

Másik oldalról akként valósult meg a költségvetési csalás büntette, hogy pályázatok folytán valótlan okiratokat csatoltak be, hogy a pályázatot elnyerjék. A nyertes pályáza- 
tok alapján megszerezett pénzösszegeket pedig saját céljukra használták fel, amelyeket szintén valótlan tartalmú okiratokkal igazoltak a támogató felé.

2015-től viszont érzékelhetően megjelentek azok az ügyek, amelyekben több számlabefogadó és kibocsátó társaság szerepel, és ezek rendszeresen több éven keresztül tartották egymással a kapcsolatot, majd okoztak nagyobb összegű adóhiányt a költségvetésnek. A résztvevők magatartását, a vádat emelő ügyészség, illetőleg a bírság jogerős döntése is bűnszövetségben vagy bűnszervezet keretén belül megvalósítottnak írta le.

Maradéktalanul egyetértek Bócz Endre 1997-ben kifejtett gondolataival, amelyek máig érvényesek: „Súlyos problémát vet fel, hogy a bűnszervezetek keretében kifejtett tevékenységek tényleges terjedelmének és a résztvevők valóságos körének, szerepének felderítése és bizonyítása a tapasztalatok szerint ritkán sikerül. Bizonytalanok a tények, nincs lehetőség a valóban szolgált büntetés alkalmazására, ez elvi síkon megkérdőjelezi a szigort, puszta deklaráció maradt. A felderítési problémák ma sem megoldottak, ez bizonyos mértékig talán már csak sajátos és egyre kevésbé hitelesen csengő magyarországi indokkal magyarázható. A szervezetbűnözés ténykedése a bűnszervezet valódi tevékenység legfőbb tagjai, vezetői, belső kapcsolatrendszere igazán csak belülről ismerhető meg. Ezen a téren lényeges körülmények kellő mélységű kiderítésére a formális büntetőeljárás keretében végzett vizsgálati tevékenység alig alkalmas. Itt tehát döntő szerepe van a titkos, különleges információszerzési módszereknek, az álcázott nyomozók, titkos informátorok alkalmazásának."77

A büntetőeljárások tapasztalatai alapján a bűnszervezetek hosszú távra rendezkedtek be, ezért azok tevékenységét mielőbb meg kell szakítani, a szervezeteket pedig felszámolni szükséges. Kulcsfontosságú kérdés, miként csökkenthető, az ehhez szükséges idő? Ezzel kapcsolatban Katona Géza már 1994-ben így írt: „A szervezett bűnözés legveszélyesebb magyarországi jelenségei azt bizonyítják, hogy a gazdaságban, a társadalomban és az igazságszolgáltatásban keletkező űrt nagyon gyorsan kihasználták a bûnözés legképzettebb és legvakmerőbb elemeit magukba foglaló »bűnöző szervezetek«, amelyek között egyaránt helyet foglalnak a hazai eredetű, vagy a külföldről beszivárgott bűnözők. A szervezett bűnözés bírói megítélése is kellene, hogy gyorsabb, hatékonyabb legyen. Ha az ítéletek nem kellő szigorúak, a végrehajtás nem hatékony, az erőszaki per tovább folytatódik."78

\section{IRODALOMJEGYZÉK}

Bencze József (2011): Szervezet ellen csak szervezettel lehet felvenni a harcot. Belügyi Szemle, 49. évf. 11. sz. 46-65.

Bezsenyi Tamás (2015): A szervezett bűnözés elleni nemzetközi együttmúködés értelmezései a magyar igazságszolgáltatásban. Polgári Szemle, 11. évf. 1-3. sz. Forrás: http://epa.oszk. hu/00800/00890/00060/EPA00890_polgari_szemle_2015_1-3_671.htm (2019. 07.01.)

Blaskó Béla (2016): Magyar büntetőjog-általános rész. Tankönyv 6. átdolgozott kiadás. Budapest-Debrecen, Rejtjel Kiadó.

77 Bócz (1997) 281-287.

78 Katona (1994) 89. 
Borai Ákos (1992): A szervezett bűnözés büntetőjogi kérdései. Rendészeti Szemle, 30. évf. 5. sz. 12-20.

Bócz Endre (1997): Egy államügyész vallomása... „a szervezetbűnözés elleni küzdelem ügyészi tapasztalatai Magyarországon”. In Sterling, Claire: Pax Mafiosa. A szervezett bünözés nemzetközi hálózata. Cedit Kft. 273-287.

Bócz Endre (2001): A szervezett bűnözés néhány problémájáról. Belügyi Szemle, 49. évf. 11. sz. 3-16

Bócz Endre (2008): A szervezett bünözésről és a bünszervezet fogalmáról. Magyar Rendészet, 8. évf. 4. sz. 5-23.

Búzás Huba - Nagy Sándor (1998): A bünszervezet fogalma. Magyar Jog, 45. évf. 4. sz. 203-206.

Búzás Huba - Nagy Sándor (1999): A bünszervezet fogalma. Büntetöjogi Tanulmányok, 1. évf. 1. sz. 47-58.

Dános Valér (1990a): A szervezett bűnözés kialakulásának néhány etiológiai kérdése. Belügyi Szemle, 28. évf. 11. sz. 25-32

Dános Valér (1990b): A szervezett bünözés néhány elméleti és gyakorlati kérdései. Főiskolai Figyelő Plusz, 1. sz. 23-33

Déri Pál (2000): A bünözési statisztika és a valóság. Budapest, BM Kiadó.

Domokos Andrea (2000): Az erőszakos bünözés. Budapest, Hinnova Magyarország Kft.

European Union Serious Organised Crime Threat Assessment 2017. Crime in the age of technology (2017). Public Version. Europol, the Hague, NL [Európai Unió Súlyos Szervezett Bünözés Fenyegetettség Értékelése. A technológia korának bünözése. Nyilvános változat. sz.n. Europol, Hága, Hollandia.] Forrás: www.europol.europa.eu/activities-services/main-reports/european-union-serious-and-organised-crime-threat-assessment-2017 (2019. 07. 01.)

European Union Organised Crime Report 2004 (2004). Open Version - December 2004. Europol, the Hague, NL. [Európai Unió Jelentés a szervezett bünözésről 2004. Nyílt változat. 2004. december. sz.n. Europol, Hága, Hollandia] Forrás: www.europol.europa.eu/activities-services/main-reports/european-union-organised-crime-report-2004 (2019. 07. 01.)

Fayer László (1905): A magyar büntetőjog kézikönyve. Budapest, Franklin Társulat

Finszter Géza - Irk Ferenc (2001): Gazdasági-társadalmi változások, a bűnözés új kihívásai (Szervezett bűnözés Kelet-Közép- Európában, az Európai Unió peremén). Kriminológiai tanulmányok, 38. köt. 11-59.

Gellér Balázs József (2004): Gondolatok az anyagi büntetőjog jelentőségéről a szervezett bủnözés elleni fellépéssel kapcsolatban. In Gellér Balázs József - Hollán Miklós szerk.: A szervezett bünözés arcai. Budapest, Rejtjel Kiadó. 11-45.

Gönczöl Katalin (1987): Bünözés és társadalompolitika. Szociológiai Tanulmányok. Budapest, Akadémia Kiadó.

Hajdu Lajos (1971): Az első (1795-ös) magyar büntetökódex tervezete. Budapest, KJK.

Irk Ferenc (1998): Szervezett bünözés - Veszély a régió fiatal demokráciáira. Collega, 2. évf. 2. sz. 13-16.

Katona Géza (2000): Szervezett bünözés Magyarországon. Budapest, Belügyminisztérium K.

Katona Géza (1994): A nemzetközi szervezett bűnözés magyarországi tevékenységével kapcsolatos kérdésekről. In Kerezsi Klára szerk.: Kriminológiai Közlemények. 49. sz., Budapest, Magyar Kriminológiai Társaság. 82-89.

Madai Sándor (2011): A csalás büntetőjogi értékelése. Budapest, HVG-ORAC Lap- és Könyvkiadó Kft.

Németh László (1992): A privatizáció és a bűnözés. Rendészeti Szemle, 30. évf. 1. sz. 52-56.

Németh Zsolt (2001): A szervezett bűnözés és a fiatalkori bűnözés összefüggései. Rendvédelmi Füzetek, 29. sz. 3-32.

Rosta Andrea (2016): Vagyon elleni bűnözés. In Borbíró Andrea - Gönczöl Katalin - Kerezsi Klára Lévay Miklós szerk.: Kriminológia. Budapest, Wolters Kluwer. 421-449.

Szabó András (1987): Új jelenségek a bünözésben és a megelőzésben. Belügyi Szemle, 25. évf. 9. sz. 6372.

Szabó Géza (1992): A szervezett bünözés elleni küzdelemről. Ügyészek Lapja, 4. sz. 49-73.

Szokolay István (1848): Büntetố jogtan. Pest, Heckenast Gusztav Kiadó.

Szőcs László (2000): Néhány gondolat a gazdasági bủnözésről. In Tauber István szerk.: Tanulmányok Vig József 70. születésnapjára. Budapest, ELTE Állam- és Jogtudományi Kar. 219-236. 
Tauber István (2000): A bűnözés várható alakulása Magyarországon. In Tauber István szerk.: Tanulmányok Vig József 70. születésnapjára. Budapest, ELTE Állam- és Jogtudományi Kar. 237-252

Tóth Mihály (2009): Bünszövetség, bünszervezet. Budapest, Complex Kiadó.

Tóth Mihály (2015): A bűnszervezeti elkövetés szabályozásának kanyargós útja. Magyar Jog, 62. évf. 1. sz. 1-10

Tóth Mihály - Kőhalmi László (2016): A szervezett bünözés. In Borbíró Andrea - Gönczöl Katalin Kerezsi Klára - Lévay Miklós szerk.: Kriminológia. Budapest, Wolters Kluwer. 603-625.

\section{Jogszabályok}

1843-ik magyar büntető törvénykönyvi javaslat (1965). Kugler Adolf Pesti Könyvárus Kiadója.

1878. évi V. Törvényczikk, A magyar Büntető Törvénykönyv, a bűntettekről és a vétségekről (1911). Magyar Törvények, Budapest, Révai Testvérek Irodalmi Intézet.

Hatályos Anyagi Büntetőjogi Szabályok Hivatalos Összeállítása (1952). Budapest, Jogi és Államigazgatási Könyv- és Folyóiratkiadó.

1961. évi V. törvény a Magyar Népköztársaság Büntető Törvénykönyve (1962). Budapest, Közigazgatási és Jogi Könyvkiadó.

1978. évi IV. Büntető Törvénykönyv

A hatályos Büntető anyagi jogszabályok és a vonatkozó Alkotmánybírósági és Legfelsőbb Bírósági iránymutatások gyújteménye (1999). Miskolc, Borsodi nyomda Kft.

1997. évi LXXIII. törvény a Büntető Törvénykönyvről szóló 1978. évi IV. törvény módosításáról 2282/2000. (XI. 29.) Korm. határozat

1998. évi LXXXVII. törvény a büntető jogszabályok módosításáról

2001. évi CXXI. törvény a Büntető Törvénykönyvről szóló 1978. évi IV. törvény módosításáról

2012. évi C. törvény a Büntető Törvénykönyvről

2019. évi LXVI. törvény Magyarország 2020. évi központi költségvetésének megalapozásáról

\section{ABSTRACT}

\section{The Relationship between Criminal Organisations and Budget Fraud in Hungary} BALLÁNÉ SZENTPÁLI Edit

During the years following the regime change, a never experienced wave of crimes swept through Hungary. A new age of organised crime has been opened due to the weight and strength of the fact that an entire organisation stood behind the perpetrators. In this early stage, organised crime was typically associated with high-tax (excise) products and the attainment of unauthorised tax claims and other economic misconduct. Perpetrators could realise a significantly higher profit than they could possible achieve pursuing legal activities. The number of carousel fraud cases have increased at the courts since 2015. Chains of companies issuing and accepting invoices have appeared in these cases causing significant damage for the state budget. Quite often, these issues remained undetected for several year-long periods until they became identified by the investigative authorities. Both prosecution and the court's final decision convicted these activities as criminal organisations. Based on the experiences of judicial procedures, the criminal organisations are to be dismantled as soon as possible. Hence, the most critical question is how to reduce the time frames dismantling would take?

Keywords: budget fraud, criminal organisations 